\title{
Aging of mesenchymal stem cell in vitro
} Mandana Mohyeddin Bonab*1, Kamran Alimoghaddam¹, Fatemeh Talebian ${ }^{2}$, Syed Hamid Ghaffari ${ }^{1}$, Ardeshir Ghavamzadeh ${ }^{1}$ and Behrouz Nikbin ${ }^{2}$

\author{
Address: ${ }^{1}$ Hematology-Oncology \& BMT Research Center, Shariati Hospital, Tehran University of Medical Sciences, Iran and ${ }^{2}$ Immunogenetics lab, \\ Dept. of Immunology, College of Medicine, Tehran University of Medical Sciences, Tehran, Iran \\ Email: Mandana Mohyeddin Bonab* - mohyeddin@sina.tums.ac.ir; Kamran Alimoghaddam - alimgh@ams.ac.ir; \\ Fatemeh Talebian - ftalebian@razi.tums.ac.ir; Syed Hamid Ghaffari - HORC@tums.ac.ir; Ardeshir Ghavamzadeh - HORC@tums.ac.ir; \\ Behrouz Nikbin -dnik@ams.ac.ir \\ * Corresponding author
}

Published: 10 March 2006

BMC Cell Biology2006, 7:14 doi:10.1 186/I47|-2121-7-14
Received: 18 April 2005

Accepted: 10 March 2006

This article is available from: http://www.biomedcentral.com/I47I-2I2I/7//4

(c) 2006Bonab et al; licensee BioMed Central Ltd.

This is an Open Access article distributed under the terms of the Creative Commons Attribution License (http://creativecommons.org/licenses/by/2.0), which permits unrestricted use, distribution, and reproduction in any medium, provided the original work is properly cited.

\begin{abstract}
Background: A hot new topic in medical treatment is the use of mesenchymal stem cells (MSC) in therapy. The low frequency of this subpopulation of stem cells in bone marrow (BM) necessitates their in vitro expansion prior to clinical use. We evaluated the effect of long term culture on the senescence of these cells.
\end{abstract}

Results: The mean long term culture was 118 days and the mean passage number was 9 . The average number of PD decreased from 7.7 to 1.2 in the 10th passage. The mean telomere length decreased from $9.19 \mathrm{Kbp}$ to $8.7 \mathrm{kbp}$ in the 9 th passage. Differentiation potential dropped from the 6th passage on. The culture's morphological abnormalities were typical of the Hayflick model of cellular aging.

Conclusion: We believe that MSC enter senescence almost undetectably from the moment of in vitro culturing. Simultaneously these cells are losing their stem cell characteristics. Therefore, it is much better to consider them for cell and gene therapy early on.

\section{Background}

Mesenchymal stem cells (MSC) are of great therapeutic potential because of their ability to self-renew and differentiate into multiple tissues[1]. They enhance engraftment of donor hematopoietic cells after cotransplantation in animal models[2]. In humans, MSC have been used to regenerate the marrow microenvironment after myeloablative therapy[3]. Possible clinical applications proposed for MSC include: stem cell transplantation[4], stem cell strategies for the repair of damaged organs[5] and gene therapy[6]. Friedenstein first described[7] MSC in bone marrow (BM) as a very rare population $(0.01 \%$ to $0.001 \%)$, and Wexlel et al[8] reported a 1 in $3.4 \times 104$ frequency for these cells. We estimated that about 1 in $3.1 \times 104$ bone marrow mononuclear cells are MSC (unpublished data). Their level is even lower in cord blood9 and peripheral blood. Thus, it is essential to culture and populate MSC in vitro before putting them to therapeutic use. Scientific literature state that telomere length shortens after each division cycle. This leads to a gradual senescence. However, in vitro culture has proven that environmental conditions and differing treatment significantly increase or decrease culture life span. It seems as though depending on conditions cells 

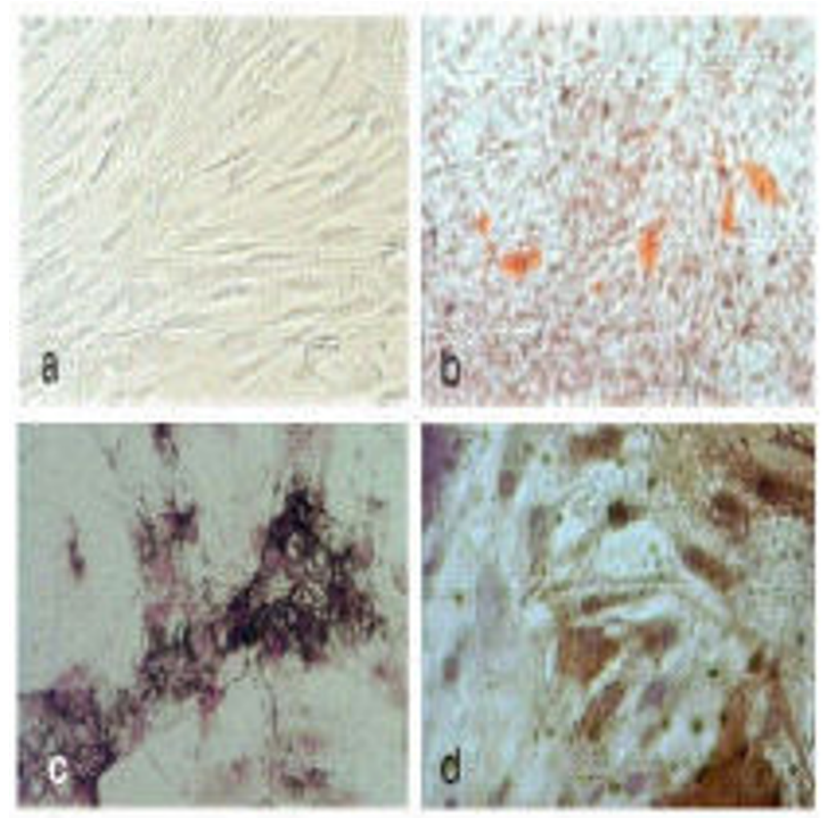

\section{Figure I}

a) Bone Marrow MSC in conventional culture (adherent, elongated cells); b) Oil red $\mathrm{O}$ staining showing fat accumulation in adipocytes. c \& d) Van Kossas and Alkaline Phosphatase staining showing osteocytes differentiation of MSC.

are exposed to, rate of decrease in telomere length varies, leading to the observed differences. For example, Van Zglinicki et al reported that cells incubated in $40 \%$ oxygen soon stopped growing and, at the same time, had shortened telomeric DNA. They showed that telomeric DNA can be lost without cell division, perhaps by single-strand breaks

in

DNA[10].

With this in mind, we designed a study to evaluate the effect of long term invitro culture on the proliferation, differentiation, telomere length, phenotype, and morphology of these cells.

\section{Results}

The results of MSC culture

Three days after plating BM mononuclear cells in culture flasks, the mean number of fibroblast like cells were about 6800 (90 cell/cm2) of total heterogeneous cells. Gradually, the fibroblast like cells (MSC) increased and the heterogeneous cells decreased in the culture.

The predominant cell after 2 weeks of culture was fibroblast like (Fig. 1a) and dislodged readily on trypsinization in 3 minutes.

Primary culture took between 11 and 25 days (mean: 15.6 day). The total count of harvested cells from primary cul- ture was between $5.4 \times 105$ and $39.0 \times 105$ (mean: $17.0 \times$ 105 cell). The mean number of harvested MSC and the mean time of confluency from the second culture on is shown in table 1 . As can be seen in table 1, the average number of cells that proliferate during each passage and the average confluency time in the various passages are different. To analyze these differences we performed the Repeated Measurement Analysis of Variance statistical test, but we did not find any significant difference between the different passages.

To evaluate whether donor age affects in vitro cell senescence, we divided our donors into two groups. The first group included 6 individuals under the age of 10, and the remaining 5 who were between the ages of 23-63 made up the second group.

Independent sample Test and Repeated Measurement Analysis was performed to evaluate telomere length, PD level, harvested cell dose and confluency time for each passage. No significant difference was observed.

The goal of this study was keeping the MSC in the culture by multiple passages up to 120 days. Nine of the 11 samples survived between 100 and 164 days and were passaged between 8 to 10 times. Two samples survived up to 63 and 95 days, and were passaged 5 and 6 times respectively (they didn't undergo the full procedure due to contamination).

\section{Immunophenotype of MSC}

The mean percent of CD expression of the three antigens in 5 different passages was compared using Repeated Measurement Analysis of Variance test. Results demonstrate no significant difference in their expression. These cells stained positively for CD44 and CD13 but negative or very low positive for CD34.

\section{Differentiation of BM MSC}

MSC were differentiated along adipogenic and osteogenic lineages. Oil red $\mathrm{O}$ staining for adipocyte and Van Kossas and Alkaline phosphatase staining for osteocyte were positive (Fig. 1b). Adipogenic differentiation of MSC after 23 weeks incubation in adipocyte culture media demonstrated scattered aggregates of oil red o positive staining cells. But within the same time limit, the osteocyte culture media exhibited a homogeneous and relatively abundant number of Van Kossas positive cells.

The differentiation ability of MSC varied in the 5 different passages. Every one of the samples cultured in osteogenic and adipogenic mediums differentiated to osteocyte and adipocytes by the 4 th culture. In the 8 th passage, $25 \%$ (2 of 8 ), and in the 10th passage, $20 \%$ ( 1 of 5 ) of the samples lost their osteogenic differentiation potential. For adi- 
Table I: The result of the mean and SD of BM-MSC culture.

\begin{tabular}{|c|c|c|c|c|}
\hline passage number & $\begin{array}{c}\text { Mean number of harvested } \\
\text { cell }\left(\times 10^{4}\right) \pm S D\end{array}$ & $\begin{array}{l}\text { Mean time of counfluency } \\
\text { (day) } \pm \text { SD }\end{array}$ & Mean number of $P D \pm S D$ & $\begin{array}{l}\text { Mean number of telomere } \\
\text { length }(\mathrm{Kbp}) \pm \mathrm{SD}\end{array}$ \\
\hline I th $_{\text {passage }}$ & $170 \pm 105.26$ & $15 \pm 4.23$ & $7.7 \pm .55$ & $9.2 \pm .60$ \\
\hline $2^{\text {th }}$ passage & $404 \pm 190.72$ & $10 \pm 4.78$ & $3.1 \pm .67$ & - \\
\hline$\left.3\right|^{\text {th }}$ passage & $280 \pm 148.52$ & $12 \pm 4.10$ & $2.6 \pm .68$ & $9.0 \pm .56$ \\
\hline $4^{\text {th }}$ passage & $283 \pm 103.55$ & $12 \pm 1.75$ & $2.6 \pm .58$ & - \\
\hline $5^{\text {th }}$ passage & $258 \pm 109.73$ & $14 \pm 4.76$ & $2.5 \pm .56$ & $8.9 \pm .58$ \\
\hline $6^{\text {th }}$ passage & $232 \pm 122.26$ & $16 \pm 5.94$ & $2.3 \pm .6 \mathrm{I}$ & - \\
\hline $7^{\text {th }}$ passage & $206 \pm 152.95$ & $14 \pm 5.27$ & $2.0 \pm .81$ & $8.8 \pm .56$ \\
\hline $8^{\text {th }}$ passage & $175 \pm 77.57$ & $|4 \pm 4.7|$ & $1.9 \pm .69$ & - \\
\hline 9th passage & $210 \pm 134.06$ & $17 \pm 4.65$ & $2.1 \pm .82$ & $8.7 \pm .75$ \\
\hline $10^{\text {th }}$ passage & $109 \pm 61.68$ & $15 \pm 3.35$ & $\mathrm{I} .2 \pm .73$ & - \\
\hline
\end{tabular}

pocytes, in the 6 th passage $10 \%$ ( 1 of 10 ), in the 8 th passage $50 \%$ ( 4 of 8 ), and in the 10th passage $60 \%$ (3 of 5) of the samples lost their adipogenic differentiation potential. The percentage of samples with the ability to differentiate into osteocyte and adipocyte in advancing CPD is shown in table 2.

\section{Long-term growth kinetics}

To examine long-term growth kinetics of MSC culture, we measured cumulative population doublings (PDs), with respect to the passage number in multiple donors. The average number of cumulative PD in 130 days was about 30 (range 26-32). MSC underwent an average of 7.7 PDs prior to the first passage. The mean PD and growth kinetics of different samples upon subsequent passages is shown in table 1 and Figure 1d, respectively.

\section{Morphological characteristics of BM MSC in long-term culture}

After a long period of normal growth, MSC culture showed abnormalities typical of the Hayflick model of cellular aging in cultured human fibroblasts 12 . The cells varied in size and shape, the cytoplasm began to be granular with many cell inclusions, and debris was formed in the medium. On average, granules were noted in the cytoplasm after 84 days (range: 62-122), while debris formation was observed in medium after about 72 days (range: 35-97) after primary culture. However, in later stages, around day 120 in some cultures, the granular cell began to be vacuolated, rounded and finally detached from the base of the flasks.

\section{Telomere length of MSC}

The range of the MTRFL varied between $10.2 \mathrm{kbp}$ to 7.8 $\mathrm{kbp}$ in different BM samples and in different passages. mTRFL decreased from an average of $9.19 \mathrm{kbp}$ in the first passage to $8.75 \mathrm{kbp}$ in the 9th passage (Fig. 2), giving a telomere shortening of about $0.44 \mathrm{kbp}$ within 120 days of expansion (table 1).

\section{Discussion}

Since MSC can differentiate into multiple tissues in vitro and in vivo, they attract a lot of attention in cell and gene therapy. The low frequency of MSC in BM[7,8] necessitates their in vitro expansion prior to clinical use. It is known that when the cells become senescent, they are unable to proliferate further. As a result, it is necessary to evaluate the proliferative capacity of expanded MSC to maintain long-term tissue regeneration before re-infusion.

The key feature of senescence in dividing cells is a long period of normal growth followed by cessation of growth. So, throughout their life span, certain events must bring about senescence. Our study has shown a number of changes in physiological, functional, and molecular parameters that occurred during long-term cultures. These changes included:

- Typical Hayflick Phenomenon of cellular aging

- Gradual decreasing proliferation potential

- Telomere shortening

- Impairment of functions

The actual age of a culture is normally recorded in population doublings (PDs). Colter et al[13] reported that the single-cell-derived colonies of MSC can be expanded up to as many as 50 PDs in about 10 weeks. But we found that MSC can be expanded up to 30 PDs, similar to Kassem et al11, in about 130 days ( 18 weeks).

The curve relationship between cumulative PD and duration of culture demonstrates a relatively linear decreasing $\mathrm{PD}$ rate with the progression of time. Furthermore, an appreciable decrease in the number of PD was seen in the latter days (more than 130 days in culture), suggesting that MSC proliferative potential decreases faster after 120 
Table 2: The percent of samples which differentiate to adipocyte and osteocyte in ongoing CPDs after 2-3 week culture period is shown here.

\begin{tabular}{lcc}
\hline CPD No. & Adipocytes & Osteocytes \\
\hline 10 & $100 \%$ & $100 \%$ \\
15 & $100 \%$ & $100 \%$ \\
20 & $90 \%$ & $90 \%$ \\
25 & $50 \%$ & $75 \%$ \\
30 & $40 \%$ & $80 \%$ \\
\hline
\end{tabular}

days in vitro expansion. To investigate the aging of MSC morphologically, we studied the culture for the presence of any abnormalities in cell morphology. Production of debris in the medium and granules in the cytoplasm has been used as markers for fibroblast aging in vitro[14]. In the present study, granulated cytoplasm and debris was observed and increased from the third month on.

We investigated another marker for cellular senescence, normally the mean telomere length. In the absence of the enzyme telomerase, telomeres gradually get shorter as cell division proceeds, and shortening of telomere throughout the life span is well-documented[15]. The consequence maybe the inactivation of genes closest to the telomere sequences, either directly or indirectly by a position effect, perhaps involving the formation of heterochromatin. However, maintenance of telomere length has been observed in germ cells, some stem cells and malignant cells due to activation of the telomerase enzyme[16].

Our present study shows that MSC senescence is associated with telomere shortening during in vitro expansion. The rate of telomere shortening was $100 \mathrm{bp}$ in every two passage. Other studies $[17,18]$ have shown that the telomere length of MSC shortens in culture expansion. However the rate of telomere shortening in Kassem et al[11] study was $100 \mathrm{bp} / \mathrm{PD}$, which is very high in comparison to our study. This difference maybe due to the long period of their culture ( $>500$ days) in comparison to our study (120 days). They showed that mTRFL decreased from an average of $10.4 \mathrm{~kb}$ in early passage cells to $7.1 \mathrm{kbp}$ in late passage cells. Although loss of mTRFL in later passages is high but the mean amount of shortening was divided by the cumulative PD number. This could partly explain the difference.

In addition to the telomere length shortening, we investigated the osteogenic and adipogenic differentiation capacity of MSC. MSC differentiation into other lineages has been used as a marker for the multipotential nature of these cells[19]. In our study, the differentiation potential to adipocyte and osteocyte dropped in the late-passages,

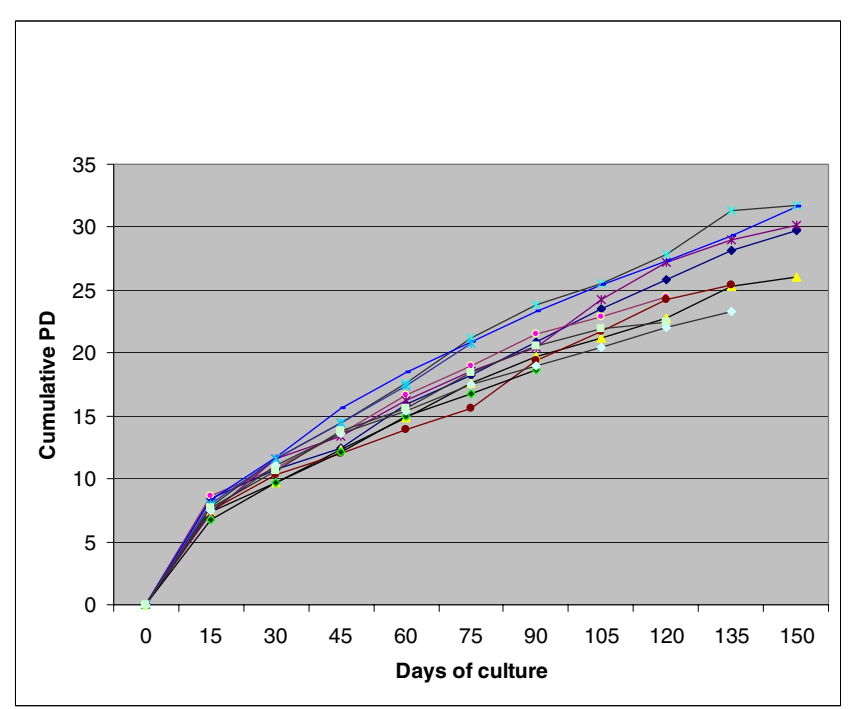

Figure 2

Long term growth curves; each obtained from an individual donor.

similar to previous reports[20,21]. Our study also demonstrated that, in the later passages, a greater number of samples lose their adipocyte differentiation potential in comparison to osteocytes in the same condition. At the level of one culture plate, the percentage of cells that differentiated into adipocyte were lower than those differentiating into osteocytes.

It is generally agreed that senescent cells are irreversibly blocked in cell division, but they are still capable of many other cell functions. According to the telomere theory of cellular senescence, the shortening of chromosome ends would itself trigger a cell cycle block.

Stenderup et al.[11] showed that donor age affects rate of in vitro senescence in MSC. They define their old age group as above 66 years of age, and compare this with a group of donors ranging from 18-29 years. The difference they observe is significant. In our study, no significance in age difference was observed. This could be directly due to the donor age we had (all below 63 and six below 10).

When there is talk of aging, transformation and tumorigenesis inevitably lingers in the background. In some cases, we observed changes from elongated adherence cells to rounded non-adherent cells after 120 days. Today, this phenomenon is noted as a mark of transformation into cancerous cells. Interestingly, recent studies highlight this issue in invitro culturing. Rubiro et al.[22] demonstrated that adipocyte tissue derived hMSC under long term culture conditions, upon entering old age, spontaneously transform into small, clustered aggregations dis- 


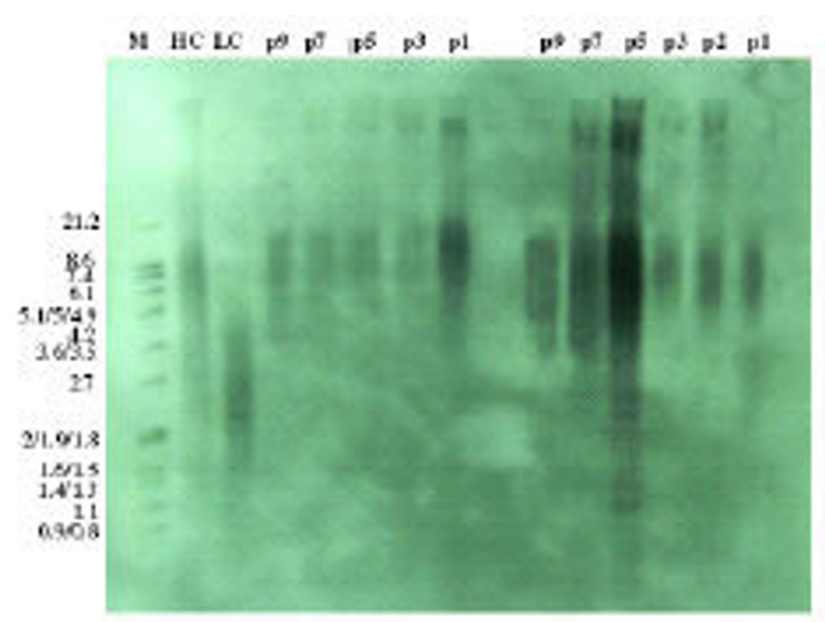

\section{Figure 3}

Southern-blot analysis of telomere lengths of expanded MSCs derived from two BM samples during multiple passages $(\mathrm{CH}=$ Control-DNA, High, $\mathrm{CL}=$ Control-DNA, Low, $\mathrm{P}=$ Passage).

playing molecular and chromosomal changes and abnormalities at a rate of $50 \%$ or so. Serakinci et al.[23] report a similar change in long term culture. They note that transduced cells develop characteristics which correlate with the acquisition of tumorigenic phenotype (loss of contact inhibition, cell cycle regulation alteration, senescence, ...) in PDL above 70. They report that these cells do not undergo such alterations in lower PDs. It is notable that as cells age, transformations become more common.

\section{Conclusion}

Our results suggest that MSC enter senescence and start to lose their stem cell characteristics almost undetectably from the moment in vitro culture begins. MSC should therefore be considered for cell and gene therapy only at the early stages of in vitro culture.

\section{Methods \\ Sample collection and MSC cultures}

Ten $\mathrm{ml}$ of BM was obtained from 11 (5 female, 6 male) healthy hematopoietic stem cell transplant donors. None of the donors had used any medication or growth factor at the time of collection. Informed consent according to an approved protocol by the internal medicine ethics committee was obtained. The mean age of BM donors was 25 years (range: 2.5 to 63 ).

The mononuclear cells (MNCs) were isolated from the collected samples by the Ficoll density gradient method. Then, they were washed in RPMI 1640 and resuspended at $1 \times 106$ cells $/ \mathrm{ml}$ in culture medium [Dulbecco's modified
Eagle medium, low glucose (DMEM-LG), 10\% (v/v) heatinactivated fetal bovine serum (FBS) and penicillin/streptomycin (all from Gibco)]. Twenty-one ml of Cell suspension was plated in a $75 \mathrm{~cm} 2$ flask (Greiner bio-one) for primary culture.

Flasks were incubated at $37^{\circ} \mathrm{C}$ in a humidified atmosphere of $5 \% \mathrm{CO} 2$ and fed by complete medium replacement every 4 days. When fibroblast-like cells at the base of the flask reached more than $90 \%$ confluence, adherent cells were detached using $0.25 \%$ trypsin EDTA and replated (passaged) at a density of $1 \times 104$ cells $/ \mathrm{ml}$ in two $75 \mathrm{~cm} 2$ flasks. On reaching confluence, all cultures were passaged sequentially up to 120 days. For every even passage, some of the expanded MSC was separated for adipocyte and osteocyte differentiation potential and immunophenotype testing. For every odd passage, the cells were examined for telomere length.

\section{Immunophenotyping}

Surface expression of CD44, CD13 and CD34 was determined on culture-expanded MSC. The monoclonal antibodies used were anti-CD44 fluorescein isothiocyanate (FITC), anti-CD13 phycoerythrin (PE), and anti-CD34 FITC (all from Dako). Relevant isotope control antibodies were also used. Flow cytometry was performed on a FACScan (Becton Dickinson), and data were analyzed with Cellquest software.

\section{Differentiation of MSC}

Adipogenic differentiation was assessed by incubating the cells with DMEM-LG and 10\% FBS supplemented with $0.5 \mu \mathrm{M}$ hydrocortisone, $0.5 \mu \mathrm{M}$ isoboutyl methylxanthine, $60 \mu \mathrm{M}$ indomethacin (Sigma-Aldrich), and $10 \mu \mathrm{g} /$ $\mathrm{ml}$ insulin (R\&D) for 2-3 weeks. Adipocyte is recognized by the accumulation of lipid-containing vacuoles which stain red with Oil red $\mathrm{O}$.

Osteogenic differentiation was assessed by incubating the cells with DMEM-LG and 10\% FBS supplemented with $0.1 \mu \mathrm{M}$ dexamethasone, $10 \mu \mathrm{M} \beta$-glycero-phosphate, and $50 \mu \mathrm{M}$ ascorbate (all from Sigma-Aldrich) for 2-3 weeks. To assess mineralization, cultures were stained with silver nitrate (Von Kossa's staining).

\section{Determination of population doubling level and morphological characteristics of long term culture}

Long-term cell growth in vitro is a sensitive method to detect subtle changes in the kinetics of proliferation of the cell population. To determine the number of cumulative population doublings, $\mathrm{BM}$ mononuclear cells were seeded $1 \times 106 \mathrm{cell} / \mathrm{ml}(28 \times 104 \mathrm{cell} / \mathrm{cm} 2)$ in T-75 flasks. The adherent MSC were counted after 3-4 days to quantify the initial number. At confluence, the cells were trypsinized, counted and reseeded at a density of $1 \times 104 / \mathrm{ml}(2.8 \times$ 
$103 \mathrm{cell} / \mathrm{cm} 2)$. The numbers of PDs were calculated using the formula $\log \mathrm{N} / \log 211$, where $\mathrm{N}$ is the cell number of the confluent monolayer divided by the initial number of cells seeded. This procedure was repeated in every passage.

To study the morphological characteristics, cell culture flasks were observed every time at medium re-feeding intervals (every 4 day), to detect any abnormalities in cell morphology and medium. When any variation was observed, the changes were recorded in the culture files.

\section{Determination of telomere length}

For telomere length assay, we used the "Telo TAGGG Telomere Length Assay" kit (Roche Molecular Biochemical) according to the manufacturer's recommendations. Briefly, the test principle is as follows: The genomic DNA was isolated and digested using restriction enzymes RsaI and HinfI for $2 \mathrm{~h}$ at $37^{\circ} \mathrm{C}$. The DNA fragments were separated by gel electrophoresis for $2-4 \mathrm{~h}$ at $70 \mathrm{~V}$ on a $0.8 \%$ agarose gel and transferred to a nylon membrane by Southern blotting.

The blotted DNA fragments are hybridized to a digoxigenin (DIG)-labeled probe specific for telomeric repeats and incubated with a DIG-specific antibody covalently coupled to alkaline phosphate. Finally, the immobilized telomere probe is visualized by virtue of alkaline phosphatase metabolizing CDP-Star, a highly sensitive chemiluminescence substrate. The average TRF length can be determined by comparing the signals relative to a molecular weight standard.

After exposure of the blot to an X-ray film, the mean TRF length were scanned and calculated by the multianalizor (Bio-rad) software.

\section{Statistical analysis}

All data are presented as mean \pm SD. The data collected in ten passages was compared by Repeated Measurement analysis of variance test. $\mathrm{P}$. values of less than $\mathrm{P}<0.05$ were considered significant.

\section{Authors' contributions}

MMB: Cell culture, differentiation, Imuunophenotyping, Telomere Assay, and was the main designer and coordinator of the study

KA: Sample Aspiration

FT: participated in Cell culture and writing of the manuscript

SHG: participated in Telomere assay

AG: participated in coordination of study
BN: Supervisor and thesis advisor, participation in design of study

All authors read and approved the final manuscript.

\section{Acknowledgements}

We would like to thank Mrs. Maryam Bashtar for her help in the culture room. This study was supported by a grant for Tehran University of medical Sciences.

\section{References}

I. Gerson SL: Mesenchymal stem cells: no longer second class marrow citizens. Nat Med I999, 5(3):262-4.

2. Anklesaria P, Kase K, Glowacki J, Holland CA, Sakakeeny MA, Wright JA, FitzGerald TJ, Lee CY, Greenberger JS: Engraftment of a clonal bone marrow stromal cell line in vivo stimulates hematopoietic recovery from total body irradiation. Proc Natl Acad Sci U $S$ A 1987, 84(2I):768I-5.

3. Koc ON, Gerson SL, Cooper BW, Dyhouse SM, Haynesworth SE, Caplan Al, Lazarus HM: Rapid hematopoietic recovery after coinfusion of autologous-blood stem cells and cultureexpanded marrow mesenchymal stem cells in advanced breast cancer patients receiving high-dose chemotherapy. J Clin Oncol 2000, I 8(2):307-I6.

4. Devine SM, Hoffman R: Role of mesenchymal stem cells in hematopoietic stem cell transplantation. Curr Opin Hematol 2000, 7(6):358-63.

5. Bruder SP, Kurth AA, Shea M, Hayes WC, Jaiswal N, Kadiyala S: Bone regeneration by implantation of purified, culture-expanded human mesenchymal stem cells. J Orthop Res 1998, I 6(2): 155-62.

6. Fukuda K, Sakamoto N, Narita T, Saitoh K, Kameda T, Iba H, Yasugi $\mathrm{S}$ : Application of efficient and specific gene transfer systems and organ culture techniques for the elucidation of mechanisms of epithelial-mesenchymal interaction in the developing gut. Dev Growth Differ 2000, 42(3):207-I I.

7. Friedenstein AJ, Latzinik NW, Grosheva AG, Gorskaya UF: Marrow microenvironment transfer by heterotopic transplantation of freshly isolated and cultured cells in porous sponges. Exp Hematol 1982, I 0(2):217-27.

8. Wexler SA, Donaldson C, Denning-Kendall P, Rice C, Bradley B, Hows JM: Adult bone marrow is a rich source of human mesenchymal 'stem' cells but umbilical cord and mobilized adult blood are not. Br J Haematol 2003, I 2 I (2):368-74.

9. Cheng FJ, Zou P, Zhong ZD, Guo R, Xiao J: The growth characteristics of mesenchymal stem/progenitor cells in human umbilical cord blood. Zhongguo Shi Yan Xue Ye Xue Za Zhi 2003, I I (6):565-8.

10. Van Zglinicki T, Saretzki G, Docke W, Lotze C: Mild hyperoxia shortens telomeres and inhibits proliferation: a model for senescence? Exp Cell Res 1995, 220:186.

II. Stenderup K, Justesen J, Clausen C, Kassem M: Aging is associated with decreased maximal life span and accelerated senescence of bone marrow stromal cells. Bone 2003, 33(6):919-26.

12. Hayflick L: The limited In Vitro lifetime of human diploid cell strains. Exp Cell Res 1965, 37:6|4-36.

13. Colter DC, Class R, DiGirolamo CM, Prockop DJ: Rapid expansion of recycling stem cells in cultures of plastic-adherent cells from human bone marrow. Proc Natl Acad Sci U S A 97(7):32 I 3-8. 2000 Mar 28

14. Smith JR, Lincoln DW 2nd: Aging of cells in culture. Int Rev Cytol 1984, 89:151-77.

15. Allsopp RC, Harley CB: Evidence for a critical telomere length in senescent human fibroblasts. Exp Cell Res 1995, 2 I 9(I): 130-6.

16. Kolquist KA, Ellisen LW, Counter CM, Meyerson M, Tan LK, Weinberg RA, Haber DA, Gerald WL: Expression of TERT in early premalignant lesions and a subset of cells in normal tissues. Nat Genet 1998, 19(2): 182-6.

17. Baxter MA, Wynn RF, Jowitt SN, Wraith JE, Fairbairn LJ, Bellantuono I: Study of telomere length reveals rapid aging of human marrow stromal cells following in vitro expansion. Stem Cells 2004, 22(5):675-82. 
18. Parsch D, Fellenberg J, Brummendorf TH, Eschlbeck AM, Richter W: Telomere length and telomerase activity during expansion and differentiation of human mesenchymal stem cells and chondrocytes. J Mol Med 2004, 82(I):49-55.

19. Pittenger MF, Mackay AM, Beck SC, Jaiswal RK, Douglas R, Mosca JD, Moorman MA, Simonetti DW, Craig S, Marshak DR: Multilineage potential of adult human mesenchymal stem cells. Science 284(54II): 143-7. 1999 Apr 2

20. Digirolamo CM, Stokes D, Colter D, Phinney DG, Class R, Prockop $D J$ : Propagation and senescence of human marrow stromal cells in culture: a simple colony-forming assay identifies samples with the greatest potential to propagate and differentiate. BrJ Haematol 1999, 107(2):275-81.

21. Conget PA, Minguell J]: Phenotypical and functional properties of human bone marrow mesenchymal progenitor cells. J Cell Physiol 1999, 18I(I):67-73.

22. Rubio D, et al.: Spontaneous human adult stem cell transformation. Cancer Res 65(8):3035-9. 2005 Apr I5

23. Serakinci $N$, et al.: Adult human mesenchymal stem cell as a target for neoplastic transformation. Oncogene 23(29):5095-8. 2004 Jun 24

Publish with Bio Med Central and every scientist can read your work free of charge

"BioMed Central will be the most significant development for disseminating the results of biomedical research in our lifetime. "

Sir Paul Nurse, Cancer Research UK

Your research papers will be:

- available free of charge to the entire biomedical community

- peer reviewed and published immediately upon acceptance

- cited in PubMed and archived on PubMed Central

- yours - you keep the copyright

Submit your manuscript here:

http://www.biomedcentral.com/info/publishing_adv.asp 